\title{
Disk Dosing Unit
}

National Cancer Institute

\section{Source}

National Cancer Institute. Disk Dosing Unit. NCI Thesaurus. Code C48490.

A dosing unit equal to the amount of active ing redient(s) contained in a disk. 